\title{
Effect of ambient temperature and feeding level on slaughter quality in fattening pigs
}

\author{
M. W. A. Verstegen ${ }^{1,3}$, H. A. Brandsma ${ }^{1}$ and G. Mateman ${ }^{2}$ \\ ${ }^{1}$ Department of Animal Husbandry, Agricultural University, P.O. Box 338, 6700 \\ AH Wageningen, Netherlands \\ ${ }^{2}$ Research Institute of Animal Production 'Schoonoord', P.O. Box 501, 3700 AM \\ Zeist, Netherlands \\ ${ }^{3}$ Department of Animal Nutrition, Agricultural University, Haagsteeg 4, 6708 PM \\ Wageningen, Netherlands
}

Received 18 September 1984; accepted 20 December 1984

Key-words: fattening pigs, feeding regimen, carcass quality

\section{Summary}

1. The purpose of the experiments was to study the effect of ambient temperature on lean and fat in the carcass after fattening either (a) at a constant feeding level of $93 \mathrm{~g} / \mathrm{kg}^{0.75}\left(1170 \mathrm{~kJ}\right.$ metabolizable energy per $\left.\mathrm{kg}^{0.75}\right)$ or (b) at equal rate of gain or (c) under ad libitum feeding conditions.

2. Seven trials with fattening pigs were performed each at two different degrees of coldness. One level was at $2 \mathrm{~K}$ below thermoneutrality (M) and the other at $6 \mathrm{~K}$ below thermoneutrality $(\mathrm{C})$. Constant coldness relative to thermoneutrality was obtained by lowering temperature by $1 \mathrm{~K}$ per $10 \mathrm{~kg}$ weight increase. The growing period was between 25 and $60 \mathrm{~kg}$ or from 60 to $100 \mathrm{~kg}$. At $60 \mathrm{~kg}$ or $100 \mathrm{~kg}$ animals were slaughtered and dissected.

3. Results showed that after the constant feeding level the lower temperature resulted in a small increase in lean-to-fat ratio as a result of less fat. Feeding the animals to an equal rate of gain or ad libitum at two different temperatures resulted in fatter carcasses at the colder housed animals than at the constant feeding level.

4. The fatter carcasses after ad libitum feeding were associated with an increased fat content in the colder-housed animals.

\section{Introduction}

The amount of energy retained by growing pigs is diminished when environmental temperature is below thermoneutrality because of increased thermal demand (Holmes \& Close, 1977). Holmes \& Close (1977) and Verstegen, Brascamp \& van der Hel (1978) have calculated the reduction in rate of body weight gain, which can be expected from such an increase in thermal demand, by assuming that the compo- 
sition of the body weight gain does not change as a result of coldness as such.

The latter assumption is questionable as some investigations have shown that the composition of the body may alter as a result of prolonged exposure to very low temperatures (Sörensen, 1962; Piatkowski, 1958). Their results suggest that fatter carcasses may be produced as a result of coldness. Results of experiments by Holme \& Coey (1967), however, indicate that fatter carcasses as a consequence of coldness are mainly due to increased feed intake. This agrees with results of studies by Comberg et al. (1971, 1972b) and Comberg et al. (1972a), with pigs fed ad libitum. They found that feed intake was increased and the lean-to-fat ratio in the carcass was reduced after the coldest fattening condition.

Contrary to these studies most reports in the literature show that coldness diminishes fat retention in preference to protein retention (Sugahara et al., 1970; Fuller \& Boyne, 1971; Hacker et al., 1973; Verstegen et al., 1973; Close \& Mount, 1976; Brown et al., 1976). Therefore, a leaner carcass can be expected at a similar feeding level in the cold. This agrees with a reduced backfat thickness measured in the pigs after fattening at low temperatures compared with thermoneutral conditions.

In the present study a series of trials was performed in strictly controlled climatic conditions to determine the effect of coldness on various aspects of carcass composition using following treatments: (a) when the pigs were fed at a constant feeding level; (b) when the pigs were kept at two degrees of coldness and fed to achieve an equal rate of gain; (c) when the pigs were fed ad libitum.

Rate of gain due to coldness at constant feeding level was depressed with about $10 \mathrm{~g} \mathrm{~K}^{-1} \mathrm{~d}^{-1}$ per animal from 25 to $60 \mathrm{~kg}$ and with about $20 \mathrm{~g} \mathrm{~K}^{-1} \mathrm{~d}^{-1}$ per animal from 60 to $100 \mathrm{~kg}$ (Verstegen et al., 1979). It was found that about $35 \mathrm{~g} \mathrm{~K}^{-1} \mathrm{~d}^{-1}$ of feed per animal was required to compensate coldness in the growth period 25 to $60 \mathrm{~kg}$. In the range 60 to $100 \mathrm{~kg}$ this amount was about $50 \mathrm{~g} \mathrm{~K}^{-1} \mathrm{~d}^{-1}$ per animal (Verstegen et al., 1982).

\section{Material and methods}

\section{Experimental design}

Table 1 shows the weight ranges and temperature treatments used in the experiments. Relative humidity was kept in $65-70 \%$ in all treatments. Each trial consisted of half a fattening period; $\mathrm{L}=25$ to $60 \mathrm{~kg}$ live weight or $\mathrm{H}=60$ to $100 \mathrm{~kg}$.

\section{Temperature treatments}

In the preliminary period the animals were kept above the effective critical temperature. In previous experiments the critical temperature for groups of animals on a similar floor and weighing about $40 \mathrm{~kg}$ had been determined to be about $15{ }^{\circ} \mathrm{C}$ (Verstegen \& van der $\mathrm{Hel}, 1974)$. It has been shown that with each $10 \mathrm{~kg}$ increase in live weight effective critical temperature is lowered by about $1 \mathrm{~K}$ (see Holmes \& Close, 1977). To provide a constant level of coldness as live weight increased, ambient temperature was lowered by $1 \mathrm{~K}$ per $10 \mathrm{~kg}$ weight increase. Similar coldness during the whole growing period was obtained by lowering ambient temperature with increase in weight. Two different degrees of coldness were used: M ( $2 \mathrm{~K}$ below 
thermoneutrality depending on the trial; (treatment $2 \mathrm{~K}$ ), and $\mathrm{C}(6 \mathrm{~K}$ below $\mathrm{M}$ depending upon the trial; (treatment $6 \mathrm{~K}$ ). At the start of the experiment temperature was set at $2 \mathrm{~K}$ and $6 \mathrm{~K}$ according to weight (see initial temperature and weight in Table 1). After each weighing the animals (each week) the temperature was adjusted to maintain $2 \mathrm{~K}$ and $6 \mathrm{~K}$ at each weight. The temperature change from start to end as measured is given in Table 1.

The experiments were planned to give information on effect of a different degree of coldness on carcass quality: (1) at a constant feeding level (T); (2) with a similar rate of gain as a littermate at thermoneutrality (P); (3) ad libitum intake at the two temperatures $(\mathrm{A})$.

Table 1. Initial and final weight of experimental groups, duration of experiments, temperature treatments. ${ }^{1}$

\begin{tabular}{|c|c|c|c|c|c|c|c|c|c|}
\hline \multirow{2}{*}{$\begin{array}{l}\text { Trial } \\
\text { No }\end{array}$} & \multirow[t]{2}{*}{$n$} & \multicolumn{2}{|c|}{ Temperature in room $\left({ }^{\circ} \mathrm{C}\right)$} & \multicolumn{2}{|c|}{ Treatments } & \multicolumn{3}{|c|}{ Weight range (kg) } & \multirow{2}{*}{$\begin{array}{l}\text { Dura- } \\
\text { tion } \\
\text { (days) }\end{array}$} \\
\hline & & start & final & feeding & coldness & initial & final & code & \\
\hline \multirow[t]{2}{*}{1} & 32 & 9.0 & 5.8 & $\mathrm{~T}$ & $\mathrm{C}$ & 59.4 & 99.2 & H & 70 \\
\hline & 32 & 12.5 & 10.1 & $\mathrm{~T}$ & $\mathbf{M}$ & 59.7 & 97.8 & $\mathbf{H}$ & 56 \\
\hline \multirow[t]{2}{*}{2} & 32 & 16.5 & 13.7 & $\mathrm{~T}$ & $\mathbf{M}$ & 25.6 & 60.7 & L & 64 \\
\hline & 32 & 14.0 & 10.6 & $\mathrm{~T}$ & $\mathrm{C}$ & 25.3 & 60.6 & L & 67 \\
\hline \multirow[t]{4}{*}{3} & 16 & 12.3 & 7.8 & $\mathrm{~T}$ & $\mathbf{M}$ & 61.2 & 103.4 & H & 56 \\
\hline & 16 & 12.3 & 7.9 & $P$ & M & 62.7 & 103.6 & $\mathrm{H}$ & 52 \\
\hline & 16 & 8.6 & 4.0 & $\mathrm{~T}$ & C & 61.1 & 101.1 & $\mathrm{H}$ & 59 \\
\hline & 16 & 8.6 & 4.0 & $\mathrm{P}$ & $\mathrm{C}$ & 60.7 & 101.7 & $\mathrm{H}$ & 52 \\
\hline \multirow[t]{4}{*}{5} & 16 & 13.5 & 10.9 & $\mathrm{~T}$ & $\mathbf{M}$ & 25.2 & 58.6 & $\mathrm{~L}$ & 59 \\
\hline & 16 & 13.5 & 10.9 & $\mathbf{P}$ & $\mathbf{M}$ & 25.7 & 60.0 & $\mathrm{~L}$ & 59 \\
\hline & 16 & 9.5 & 7.0 & $T$ & C & 25.5 & 59.6 & $\mathrm{~L}$ & 66 \\
\hline & 16 & 9.5 & 7.1 & $\mathbf{P}$ & $\mathrm{C}$ & 24.5 & 58.3 & L & 59 \\
\hline \multirow[t]{4}{*}{7} & 16 & 6.5 & 3.2 & $\mathrm{~T}$ & C & 60.8 & 100.2 & $\mathrm{H}$ & 63 \\
\hline & 16 & 6.5 & 3.2 & $\mathrm{P}$ & $\mathrm{C}$ & 60.7 & 100.5 & $\mathrm{H}$ & 56 \\
\hline & 16 & 11.4 & 7.1 & $\mathrm{~T}$ & $\mathbf{M}$ & 60.1 & 99.2 & $\mathbf{H}$ & 56 \\
\hline & 16 & 11.4 & 7.1 & $\mathrm{P}$ & $\mathbf{M}$ & 59.8 & 100.8 & $\mathbf{H}$ & 56 \\
\hline \multirow[t]{4}{*}{8} & 16 & 12.1 & 8.1 & $\mathrm{~T}$ & $\mathbf{M}$ & 26.4 & 65.7 & $\mathbf{L}$ & 70 \\
\hline & 16 & 12.1 & 9.0 & A & $\mathbf{M}$ & 26.7 & 68.1 & $\mathrm{~L}$ & 54 \\
\hline & 16 & 7.0 & 3.0 & $\mathrm{~T}$ & C & 26.7 & 67.6 & $\mathrm{~L}$ & 84 \\
\hline & 16 & 7.0 & 4.0 & A & $\mathrm{C}$ & 26.5 & 67.1 & $\mathrm{~L}$ & 60 \\
\hline \multirow[t]{4}{*}{9} & 16 & 10.4 & 5.9 & $\mathrm{~T}$ & $\mathbf{M}$ & 55.1 & 100.4 & $\mathbf{H}$ & 66.5 \\
\hline & 16 & 10.4 & 6.8 & A & $\mathbf{M}$ & 55.4 & 101.4 & $\mathrm{H}$ & 42 \\
\hline & 16 & 5.4 & 1.9 & $\mathrm{~T}$ & C & 54.1 & 102.9 & $\mathrm{H}$ & 88 \\
\hline & $\cdot 16$ & 5.4 & 2.0 & A & C & 54.7 & 101.8 & $\mathrm{H}$ & 49 \\
\hline
\end{tabular}

1 Treatments: $\mathrm{T}=$ feeding level $93 \mathrm{~g} / \mathrm{kg}^{0.75} ; \mathrm{P}=$ pair gained with thermoneutral; $\mathrm{A}=$ ad libitum. Coldness at feeding level $\mathrm{T}: \mathrm{M}=2 \mathrm{~K}$ below thermoneutral; $\mathrm{C}=6 \mathrm{~K}$ below thermoneutral. Code for weight range: $\mathrm{L}=25-60 \mathrm{~kg} ; \mathrm{H}=60-100 \mathrm{~kg}$.

Neth. J. agric. Sci. 33 (1985) 
a. In 5 trials (Nos 1, 2, 3, 5 and 7) the depression in rate of gain per $\mathrm{K}$ decrease has been estimated at a constant feeding level of $93 \mathrm{~g} \mathrm{~kg}^{-0.75} \mathrm{~d}^{-1}$.

b. In three of the trials (Nos 3,5 and 7) the amounts of feed required to compensate the reduced gain were estimated. Climatic conditions were the same as for the above trials. In two groups within a room, feeding level was similar to that above. The two other groups in each room received additional feed so that a rate of gain was achieved similar to a thermoneutral gain when $93 \mathrm{~g} \mathrm{~d}^{-1} \mathrm{~kg}^{-0.75}$ was fed (P). This level is about $1170 \mathrm{~kJ}$ metabolizable energy per $\mathrm{kg}^{0.75}$. The effects of coldness and feeding on lean and fat content in the carcasses were analysed.

c. In two trials (Nos 8 and 9) the effect of ad libitum intake compared to a constant feeding level was estimated at two different temperatures. Climatic conditions in the rooms were $2 \mathrm{~K}$ lower than in the trials above. Temperatures below thermoneutrality in these trials were $4 \mathrm{~K}(\mathrm{M})$ and $8 \mathrm{~K}(\mathrm{C})$ for the constant feeding level. These lower temperatures were applied to ensure sufficient coldness for the animals fed ad libitum.

\section{Pigs}

In all trials, pigs crossbred from Dutch Landrace and Large White were used. Animals were weaned at 5 weeks of age and had access to creep feed after 1 week of age. In all trials (except Trials 8 and 9) gilts and castrated males were used. In Trials 8 and 9 only castrates were used. In each trial performance, feed consumption, growth and carcass traits were measured individually.

\section{Housing}

All trials were performed in the climatic rooms of the Research Institute of Animal Production in Zeist. Technical data and description of the two rooms have been given previously by Simmermans \& Stadler (1976). In each room 32 pigs were housed in four groups of 8 : two groups of 8 castrated males and two groups of $8 \mathrm{fe}-$ males. The floor of the room consisted of $5 \mathrm{~cm}$ of foam with a non-toxic asphalt finish. About $1.3 \mathrm{~m}^{2}$ of bedding area and $5 \mathrm{~m}^{3}$ of air volume was available per animal. Each day some wood shavings were provided for the animals. At feeding time animals were kept seperated until feed intake of each animal was measured.

\section{Feeding}

In all trials the same type of feed was used. The composition is given elsewhere (Verstegen et al., 1982). Calculated net energy content of the feed was $8.8 \mathrm{MJ}$ per $\mathrm{kg}$ and calculated crude protein content was $13.4 \%$. Animals were fed individually twice a day with two equal portions at $8.00 \mathrm{~h}$ and at $16.00 \mathrm{~h}$. The feed was fed as a slurry with a water to feed ratio of $2: 1$. When ad libitum feeding was applied, animals had access to dry feed for $1 \mathrm{~h}$ in the morning and $1 \mathrm{~h}$ in the evening. Water was continuously available from nipples for all pigs. Feed residues were collected after each feeding time from each pig. Dry matter of the feed residues for individual animals was determined and feed intake was adjusted accordingly. 


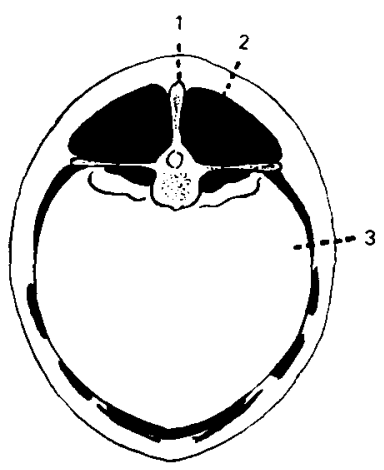

Fig. 1. Location at which backfat thickness is measured. 1, backfat thickness (midback); 2, backfat thickness (estimated ultrasonically); 3, backfat destinction 'back/belly'.

Body measurements and carcass quality were carried out as follows.

- At the end of the experimental period backfat was estimated ultrasonically (US) on the live animals as illustrated by Verstegen et al. (1979) (see Fig. 1, loc. 2). After slaughtering thickness of fat was also measured with a ruler midback at the same position (see Fig. 1, loc. 1) and also about 20-25 cm from midback (see Fig. 1, loc. 3 ). The mean of measurements at the 7/8th, 12/13th and 16/17th rib was taken.

- The carcass composition was evaluated according to the IVO standard method described by Bergström \& Kroeske (1968). In this method, lean tissue is composed of defatted ham and loin together with lean offal.

Fatty tissue is composed of: subcutaneous fat (fat on ham, belly and shoulder, backfat, lower jaw fat and fat offal) and internal fat (omental fat and intestinal fat). Subcutaneous fat is about $60 \%$ of the total fat tissue. From data of the investigations of Walstra (1980) the amounts of lean and fat tissue were estimated for each animal at the start of the experiment. Rate of gain in lean tissue (LTRG) and in fat tissue (FTGR) was calculated from lean and fat at slaughter and from the estimated contents at the start. Walstra (1980) estimated the proportion of lean at $25 \mathrm{~kg}$ live weight as $46 \%$ and at $60 \mathrm{~kg}$ as $40 \%$. For fat tissue he also developed weight-dependent equations (see Walstra, 1980 p. 147). In the trials with ad libitum feeding, additional determinations of dry matter, protein and fat content were determined in $\mathrm{m}$. longissimus dorsi (l.d.), m. supraspinatus and $\mathrm{m}$. semintendinosus. Davies \& Pryor (1977) stated that the composition of the latter two muscles is representative of mean carcass composition. The 1.d. muscle is an important measure for carcass quality of pigs.

Six body measurements were taken at the end of each trial $(60 \mathrm{~kg}$ of $100 \mathrm{~kg})$ as described by Verstegen et al. (1979). Height at shoulder, height at croup, width at shoulder, width at croup, heart girth, carcass length, cranial side of humoro scapular joint to tuber ischiadicum.

Analysis of data

Various ways of analysing the data were used. All traits were measured per animal. 
The data were analysed first with residual between pens as remainder. Analyses were done with the following models:

$\mathrm{Y}_{\mathrm{ijkl}}=\mu+\mathrm{T}_{\mathrm{i}}+\mathrm{Temp}_{\mathrm{j}}+\mathrm{Sex}_{\mathrm{k}}+$ interaction $+\mathrm{E}_{\mathrm{ijkl}}$

in which: $\mu$, mean

$\mathrm{T}_{\mathrm{i}}$, effect of trial

Temp $_{j}$, effect of temp $p_{j}$

Sex $_{\mathrm{k}}$, effect of $\operatorname{sex}_{\mathrm{k}}$

$\mathrm{E}_{\mathrm{ijk}}$, remainder (between pens)

Provisional analyses showed that remainder within pens were similar to remainder between pens.

- For each weight range and objective a test was carried out to calculate the relation between lean tissue, fat tissue and backfat thickness (US). The calculations were done by correcting simultaneously for trial, sex and treatment and taking backfat thickness within treatment as covariable.

- Body measurements of pigs in each trial were compared by Student's T-test.

\section{Results}

The aim of these experiments was to determine the effects of small changes in temperature on rate and extent of deposition of lean and fat tissue. Body weight gain in lean and fatty tissue are therefore presented in relation to feeding level and body

Table 2. Mean rate of gain in lean and fat tissue in g per day per animal. Proportion of lean and fat tissue at slaughter $(\%)$ and backfat thickness $(\mathrm{mm})$ and effect of treatments.

\begin{tabular}{|c|c|c|c|c|c|}
\hline Factors & LTGR & FTGR & Lean $(\%)$ & Fat $(\%)$ & Backfat (mm) \\
\hline \multicolumn{6}{|l|}{$60 \mathrm{~kg}$} \\
\hline Similar feed $T$ (mean) & 236 & 123 & 60.2 & 30.7 & 9.3 \\
\hline Temp. effect & * & - & - & - & - \\
\hline sex effect & * & - & * & * & * \\
\hline Similar gain $P$ (mean) & 237 & 130 & 59.5 & 31.3 & - \\
\hline Temp. $\times$ feed effect & - & $*$ & - & - & - \\
\hline sex effect & * & - & * & - & $*$ \\
\hline Ad libitum $A$ (mean) & 254 & 166 & 57.9 & 33.6 & - \\
\hline Temp. $\times$ feed effect & $*$ & - & $*$ & * & $*$ \\
\hline \multicolumn{6}{|l|}{100 kg } \\
\hline Similar feed $T$ (mean) & 269 & 210 & 56.7 & 35.7 & 25.4 \\
\hline Temp. effect & $* *$ & $* *$ & * & - & - \\
\hline sex effect & ** & - & - & _- & - \\
\hline Similar gain $P$ (mean) & 316 & 278 & 58.0 & 34.8 & - \\
\hline Temp. $\times$ feed effect & $* *$ & $* *$ & - & - & - \\
\hline sex effect & $* *$ & - & ** & $* *$ & $* *$ \\
\hline Ad libitum A (mean) & 302 & 253 & 55.4 & 34.6 & - \\
\hline Temp. $\times$ feed effect & $* *$ & $* *$ & $* *$ & $* *$ & $* *$ \\
\hline
\end{tabular}


weight range. The least square means of the analyses according to model the for various traits are presented in Table 2 together with the significance of temperature and sex.

\section{Similar feeding}

Results presented in Tables 2 and 3 show that backfat thickness (US) was not clearly affected by temperature. For rate of gain in lean tissue (LTGR), sex of animals is the most important factor and for rate of gain in fat tissue (FTGR) weight at slaughter.

Rate of gain in both lean and fat tissue were affected by temperature treatment $(P<0.01)$. The ratio of these traits however was not significantly affected by coldness, thus reflecting the growth rate of the whole animal. In Table 3, the average of backfat thickness (US) as measured in various treatments is given. Results in Table 3 and 4 suggest that method of measurement may be important. Most body

Table 3. Least square mean and mean squares of backfat thicknesses measured by weight range (R), temperature $(T)$, sex (S) and their interaction in trials of constant feeding level $93 \mathrm{~g} \mathrm{~kg}^{-0.75} \mathrm{~d}^{-1}$.

\begin{tabular}{lccccc}
\hline Variable & df & \multicolumn{2}{c}{ Fat thickness $(\mathrm{mm})$} & & \\
\cline { 2 - 6 } & & Mid-back $(1)$ & US (2) & df & side (3) \\
Mean & & 226 & 12.8 & & 13.1 \\
Temperature (T) & 1 & $8^{*}$ & 4 & 1 & 40 \\
Weight range (R) & 1 & $4937^{* *}$ & $3254^{* *}$ & & 3101 \\
Sex (S) & 1 & $370^{* *}$ & $198^{* *}$ & 1 & $61.8^{* *}$ \\
$\mathrm{~T} \times \mathrm{R}$ & 1 & 49 & 3 & 1 & $23.2^{*}$ \\
$\mathrm{R} \times \mathrm{S}$ & 1 & 13.6 & $14^{*}$ & 1 & $31.1^{*}$ \\
$\mathrm{~T} \times \mathrm{S}$ & 1 & & & & 5.3 \\
Remainder & 277 & 5.6 & 3 & 120 & 0.69 \\
$\mathrm{R}^{2}$ & & 0.75 & 0.83 & & \\
\hline
\end{tabular}

${ }^{*} P<0.05 ;{ }^{* *} P<0.01$.

Table 4. Backfat thickness $(\mathrm{mm})$, carcass length $(\mathrm{cm})$ and width at croup of animals per trial of similar feeding level. $\mathrm{M}=2 \mathrm{~K}$ below thermoneutrality, $\mathrm{C}=6 \mathrm{~K}$ below thermoneutrality.

\begin{tabular}{|c|c|c|c|c|c|c|c|c|c|c|c|}
\hline \multirow{3}{*}{\multicolumn{2}{|c|}{$\begin{array}{l}\text { Weight } \rightarrow \\
\text { Trial No } \rightarrow \\
\text { Treatment } \rightarrow\end{array}$}} & \multicolumn{4}{|c|}{$60 \mathrm{~kg}$} & \multicolumn{6}{|c|}{$100 \mathrm{~kg}$} \\
\hline & & \multicolumn{2}{|l|}{2} & \multicolumn{2}{|l|}{5} & \multicolumn{2}{|l|}{1} & \multicolumn{2}{|l|}{3} & \multicolumn{2}{|l|}{7} \\
\hline & & $\mathbf{M}$ & C & $\mathrm{M}$ & C & $\mathbf{M}$ & C & M & $\mathrm{C}$ & $\mathbf{M}$ & $\mathrm{C}$ \\
\hline \multicolumn{2}{|c|}{ Backfat at midback (mm) } & 17.4 & 17.2 & 18.4 & 18.7 & 28.5 & 27.6 & 26.4 & 27.2 & 23.6 & 23.3 \\
\hline \multicolumn{2}{|c|}{ US (mm) } & 9.0 & 9.2 & 9.7 & 9.5 & 17.3 & $18.5^{*}$ & 14.5 & 15.6 & 13.5 & 12.4 \\
\hline \multicolumn{2}{|c|}{ Carcass length $(\mathrm{cm})$} & 72.3 & 71.7 & 70.8 & 71.4 & 81.0 & 81.1 & 81.6 & 82.3 & 82.6 & 82.8 \\
\hline \multicolumn{2}{|c|}{ Width at croup $(\mathrm{cm})$} & 26.5 & $27.2^{*}$ & 26.3 & 27.6 & 30.9 & $31.6^{*}$ & 31.6 & 31.8 & 32.7 & 33.8 \\
\hline \multicolumn{2}{|c|}{ Weight at chest $(\mathrm{cm})$} & 51.5 & 51.5 & 49.7 & 49.1 & 61.1 & 58.8 & 60.6 & 59.5 & 58.6 & 57.1 \\
\hline \multicolumn{2}{|c|}{ Height at croup $(\mathrm{cm})$} & 60.1 & 59.5 & 58.4 & 58.0 & 69.1 & 67.7 & 67.9 & 68.3 & 66.7 & 67.9 \\
\hline \multicolumn{2}{|c|}{ Heart girth $(\mathrm{cm})$} & 82.7 & 82.5 & 80.6 & 81.4 & 99.4 & 99.9 & 100.4 & 101.1 & 99.8 & 99.6 \\
\hline \multicolumn{2}{|c|}{ Width at chest $(\mathrm{cm})$} & 26.0 & 25.9 & 25.6 & 26.3 & 30.9 & 31.2 & 31.5 & 32.8 & 33.0 & 33.7 \\
\hline
\end{tabular}

* $P<0.05$ (comparison $\mathrm{M}$ to $\mathrm{C}$ ).

Neth. J. agric. Sci. 33 (1985) 
Table 5. Coefficients of correlation of backfat thickness (US) with \% of lean and \% of fat in carcass (from within-treatment groups).

\begin{tabular}{lllllll}
\hline Feeding level & Coldness & \multicolumn{6}{l}{$60 \mathrm{~kg}$} & & $100 \mathrm{~kg}$ & \\
\cline { 3 - 4 } & & \% lean & \% fat & & \% lean & \% fat \\
Ad libitum & & -0.69 & 0.69 & & -0.85 & 0.87 \\
Same feed & $\mathrm{M}$ & -0.61 & 0.60 & -0.88 & 0.90 \\
Same feed & $\mathrm{C}$ & -0.66 & 0.68 & -0.72 & 0.76 \\
PAIR gained & $\mathrm{C}$ & -0.78 & 0.82 & -0.86 & 0.88 \\
PAIR gained & & -0.63 & 0.58 & -0.84 & 0.86 \\
\hline
\end{tabular}

Table 6. Change in amount of lean and fat tissue as related to backfat thickness within temperature treatment (b in $\mathrm{kg}$ per mm US) at constant feeding (T), PAIR gaining (P) and ad libitum (A).

\begin{tabular}{|c|c|c|c|c|c|c|c|c|}
\hline & \multicolumn{4}{|c|}{ At $60 \mathrm{~kg}(\mathrm{~L})$} & \multicolumn{4}{|c|}{ At $100 \mathrm{~kg}(\mathrm{H})$} \\
\hline \multicolumn{9}{|c|}{ Constant feeding (Trials $1+2$ ) } \\
\hline Feeding & \multicolumn{2}{|l|}{$\mathrm{T}$} & \multicolumn{2}{|l|}{$\mathrm{T}$} & \multicolumn{2}{|l|}{$\mathrm{T}$} & \multicolumn{2}{|l|}{$\mathrm{T}$} \\
\hline Coldness & \multicolumn{2}{|l|}{ M } & \multicolumn{2}{|l|}{$\mathrm{C}$} & \multicolumn{2}{|l|}{ M } & \multicolumn{2}{|l|}{$\mathrm{C}$} \\
\hline Lean tissue $(\mathrm{kg})$ mean & \multirow{2}{*}{\multicolumn{2}{|c|}{$\begin{array}{l}28.3 \\
-0.314\end{array}$}} & \multicolumn{2}{|l|}{28.9} & \multicolumn{2}{|l|}{44.9} & \multicolumn{2}{|l|}{46.1} \\
\hline $\mathrm{b}(\mathrm{kg} / \mathrm{mm})$ & & & \multicolumn{2}{|l|}{-0.581} & \multicolumn{2}{|l|}{-0.852} & \multicolumn{2}{|l|}{-0.859} \\
\hline \multirow{2}{*}{$\mathrm{b}(\mathrm{kg} / \mathrm{mm})$} & \multicolumn{2}{|c|}{14.5} & 0.572 & & \multicolumn{2}{|l|}{$\begin{array}{l}28.3 \\
0.924\end{array}$} & \multicolumn{2}{|l|}{$\begin{array}{l}28.8 \\
0.917\end{array}$} \\
\hline & \multicolumn{4}{|c|}{ At $60 \mathrm{~kg}(\mathrm{~L})$} & \multicolumn{4}{|c|}{ At $100 \mathrm{~kg}(\mathrm{H})$} \\
\hline \multicolumn{9}{|c|}{ Constant coldness (Trials $3,5,7$ ) } \\
\hline Feeding & $\mathrm{T}$ & $\mathrm{T}$ & $\mathbf{P}$ & $\mathrm{P}$ & $\mathrm{T}$ & $\mathrm{T}$ & $\mathrm{P}$ & $\mathrm{P}$ \\
\hline Coldness & $\mathrm{M}$ & C & M & $\mathrm{C}$ & M & C & M & $\mathrm{C}$ \\
\hline Lean tissue $(\mathrm{kg})$ mean & 27.4 & 27.9 & 27.8 & 27.2 & 46.3 & 47.5 & 47.4 & 47.0 \\
\hline $\mathrm{b}(\mathrm{kg} / \mathrm{mm})$ & -1.23 & -1.26 & -1.65 & -0.83 & -0.93 & -0.86 & -0.69 & -0.68 \\
\hline Fat tissue $(\mathrm{kg})$ mean & 14.4 & 14.3 & 14.6 & 15.7 & 27.6 & 27.6 & 28.5 & 26.6 \\
\hline $\mathrm{b}(\mathrm{kg} / \mathrm{mm})$ & 1.30 & 1.36 & 1.63 & 0.86 & 1.01 & 0.90 & 0.81 & 0.73 \\
\hline \multicolumn{9}{|l|}{ Ad libitum (Trials 8,9 ) } \\
\hline Feeding & $\mathrm{T}$ & $\mathrm{T}$ & A & A & $\mathrm{T}$ & $\mathrm{T}$ & A & A \\
\hline Coldness & M & $\mathrm{C}$ & M & $\mathrm{C}$ & M & $\mathrm{C}$ & $\mathrm{M}$ & $\mathrm{C}$ \\
\hline Lean tissue $(\mathrm{kg})$ mean & 29.1 & 30.2 & 29.1 & 28.7 & 44.7 & 44.2 & 41.4 & 42.8 \\
\hline $\mathrm{b}(\mathrm{kg} / \mathrm{mm})$ & -1.85 & -2.49 & -3.01 & -1.97 & $-1.86^{*}$ & -2.48 & -3.01 & -2.26 \\
\hline Fat tissue $(\mathrm{kg})$ mean & 15.3 & 16.6 & 18.2 & 17.8 & 16.9 & 28.5 & 30.0 & 30.2 \\
\hline $\mathrm{b}(\mathrm{kg} / \mathrm{mm})$ & 1.71 & 2.46 & 3.46 & 1.71 & $1.72^{*}$ & 2.46 & 3.45 & 2.01 \\
\hline
\end{tabular}

* b significantly different between treatments $(P<0.01)$.

measurements were not clearly affected by degree of coldness. Width of croup was increased significantly $(P<0.05)$ at treatment $C$ in two of the five trials compared to treatment $M$. Within treatment groups, the percentages of fat and lean tissue were clearly correlated with backfat thickness (Table 5). Increase in backfat was associated with decrease in lean tissue and increase in fat tissue.

Results in Table 6 show that per mm increase in backfat (US) 0.32 to $0.57 \mathrm{~kg}$ more fat tissue in a $60-\mathrm{kg}$ pig was found at treatments $M$ and $C$ respectively (n.s., not significant). Lean was diminished with 0.31 to $0.58 \mathrm{~kg}$ per mm increase in back- 
fat at $60 \mathrm{~kg}$ (n.s.). At $100 \mathrm{~kg}$ body weight however both lean and fat were significantly affected by US backfat $(P<0.01)$. The increase in fat tissue was $0.92 \mathrm{~kg}$ per $\mathrm{mm}$ at $100 \mathrm{~kg}$ and the decrease in lean $0.85 \mathrm{~kg}$ per mm extra fat. The changes in lean and fat with increase in backfat (US) were not significantly different between treatments $\mathrm{M}$ and $\mathrm{C}$ for the heavier pigs.

\section{Similar gain (PAIR gained at $M$ and $C$ )}

Feeding of pigs at $M$ and $C$ to equal rate of gain, as the assumed gain in thermoneutral conditions at $\mathrm{T}$, increased both lean and fat tissue growth rate $(P<0.01)$ (Table 2 and Fig. 2). Especially in the coldest group $C(P)$ the FTGR is significantly increased by the extra feed (Table 2 and Fig. 2). PAIR gaining causes a reduction in the ratio LTGR to FTGR $(P<0.05)$ in the weight range 60 to $100 \mathrm{~kg}$. This ratio was reduced especially under the colder conditions. Backfat thickness of pigs in the four treatment groups is presented in Fig. 3.

Results from this set of experiments did not show a significantly different regression of lean and fat tissue on backfat thickness (US) within treatments (Table 6). Amount of lean tissue decreased by 0.83 to $1.65 \mathrm{~kg}$ per mm increase in backfat at $60 \mathrm{~kg}$, and by 0.68 to $0.93 \mathrm{~kg}$ per mm at $100 \mathrm{~kg}$. The overall coefficient from all treatments in Exp. 3, 5 and 7 was $1.18 \mathrm{~kg}$ decrease in lean tissue at $60 \mathrm{~kg}$ and $0.78 \mathrm{~kg}$ at $100 \mathrm{~kg}$ per mm backfat. Fat tissue increased with 1.20 and $1.02 \mathrm{~kg}$ at $60 \mathrm{~kg}$ and $100 \mathrm{~kg}$ per mm backfat (US) respectively.

\section{Ad libitum feeding}

The ad libitum feeding of pigs at two different temperatures resulted in a great in-
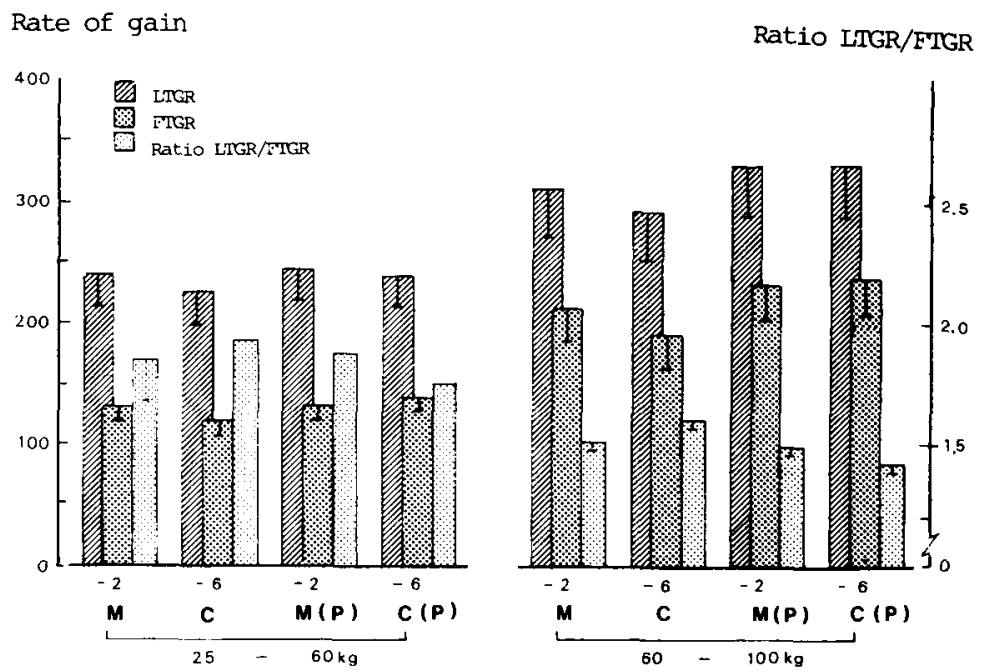

Fig. 2. Rate of gain per animal (g/day) in lean and fat tissue and their ratio in the 2 weight classes at constant feeding level and after PAIR gaining $(\mathrm{P}) . \mathrm{M}=2 \mathrm{~K}$ below thermoneutrality; $\mathrm{C}=6 \mathrm{~K}$ below thermoneutrality. 


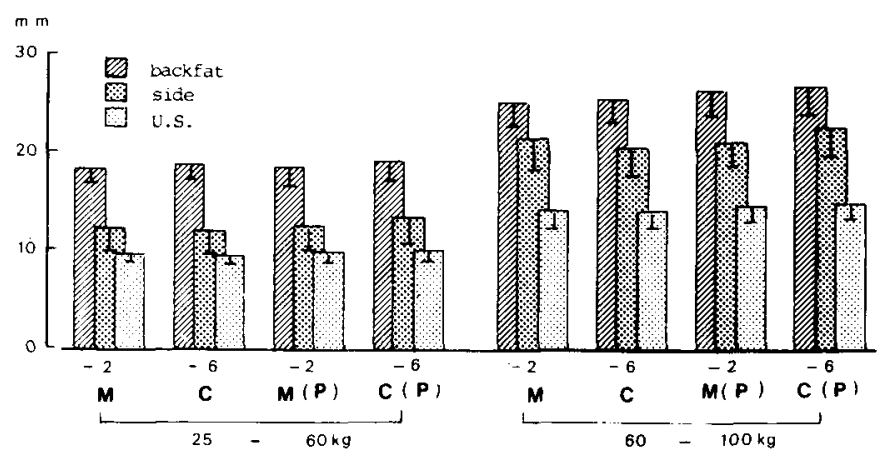

Fig. 3. Backfat thickness measured at three places after fattening at two temperatures with constant level and PAIR gaining $(P) . M=2 \mathrm{~K}$ below thermoneutrality; $C=6 \mathrm{~K}$ below thermoneutrality.

Rate of gain

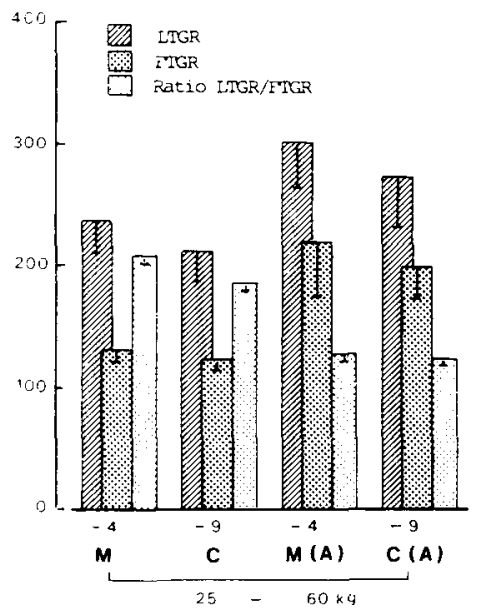

Ratio LTGR/FTGR

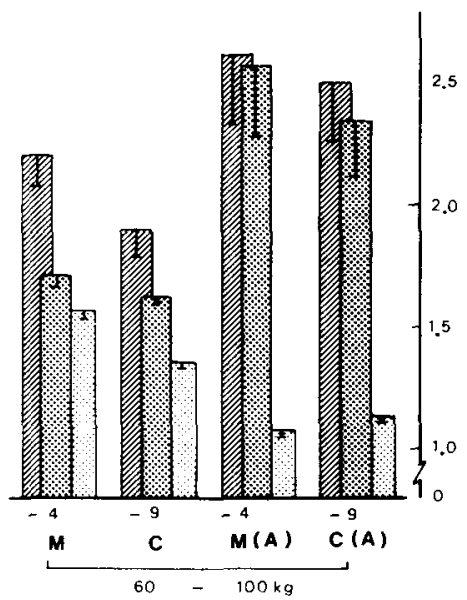

Fig. 4. Rate of gain per animal (g/day) in lean and fat and the ratio in castrates at two degrees of coldness either with constant feeding level (C) or ad libitum (A). $M=4 \mathrm{~K}$ below thermoneutrality; $C=9 \mathrm{~K}$ below thermoneutrality.

crease in gain in both LTGR and FTGR $(P<0.01)$ as compared to the constant feeding level of $100 \mathrm{~g} \mathrm{~kg}^{-0.75} \mathrm{~d}^{-1}$. These data are given in Fig. 4. However, fat gain was influenced much more by extra feed than lean tissue gain. Means of LTGR and FTGR are given in Table 2.

Ad libitum feeding caused a greater increase in LTGR and FTGR in the weight range 60 to $100 \mathrm{~kg}$ compared to 25 to $60 \mathrm{~kg}$ (Fig. 4). The extra feed appears to reduce this ratio more in the colder conditions $(\mathrm{C})$ than at moderate coldness (M).

Ad libitum intake was associated with an increased backfat thickness (US) in the castrated males (Table 2). Fat thickness at mid-back and US were increased after 
Table 7. Effect of ad libitum feeding on backfat thickness, carcass composition and body measurements at two temperatures; comparison within feeding level.

\begin{tabular}{|c|c|c|c|c|c|c|c|c|}
\hline \multirow[b]{3}{*}{ Coldness } & \multicolumn{4}{|c|}{ Weight $60 \mathrm{~kg}$} & \multicolumn{4}{|c|}{ Weight $100 \mathrm{~kg}$} \\
\hline & \multicolumn{2}{|c|}{ constant feeding } & \multicolumn{2}{|c|}{ ad libitum feeding } & \multicolumn{2}{|c|}{ constant feeding } & \multicolumn{2}{|c|}{ ad libitum feeding } \\
\hline & M & $\mathrm{C}$ & M & $\mathrm{C}$ & M & $\mathrm{C}$ & MA & $\mathrm{CA}$ \\
\hline Backfat (mm) & 18.3 & 19.5 & 21.0 & 21.3 & 24.4 & 27.2 & 27.7 & 27.8 \\
\hline US (mm) & 7.8 & 7.3 & 9.5 & 8.9 & 16.0 & 16.7 & 18.6 & 18.6 \\
\hline $\begin{array}{l}\text { Carcrass length } \\
(\mathrm{cm})\end{array}$ & 72.4 & $69.9^{* *}$ & 72.5 & 71.7 & 81.2 & 80.3 & 82.4 & 81.4 \\
\hline $\begin{array}{l}\text { Width at croup } \\
(\mathrm{cm}) \\
\text { Height at chest }\end{array}$ & 24.1 & $25.4^{*}$ & 24.5 & 26.7 & 30.4 & $31.5^{*}$ & 30.3 & $31.5^{*}$ \\
\hline $\begin{array}{l}\text { (cm) } \\
\text { Height at croup }\end{array}$ & 55.7 & 56.5 & 56.6 & 56.6 & 59.7 & 60.2 & 60.7 & 60.2 \\
\hline $\begin{array}{l}(\mathrm{cm}) \\
\text { Heart girth }\end{array}$ & 63.2 & 63.2 & 63.4 & 64.0 & 68.0 & 68.7 & 67.7 & 67.1 \\
\hline $\begin{array}{l}(\mathrm{cm}) \\
\text { Width at chest }\end{array}$ & 83.9 & 85.0 & 86.5 & 87.0 & 97.7 & 98.3 & 99.8 & 99.7 \\
\hline$(\mathrm{cm})$ & 23.0 & 23.9 & 24.2 & 25.8 & 30.0 & 30.3 & 30.3 & 30.8 \\
\hline
\end{tabular}

* $P<0.05$; ${ }^{* *} P<0.01$.

ad libitum feeding (Table 7). The shortest carcasses were produced at the lowest temperatures (Table 7). These animals also showed the greatest width at croup ( $P$ $<0.05$ ). Correlation coefficients between $\%$ of lean and fat with backfat thickness (Table 5) are of similar magnitude. At $100 \mathrm{~kg}$ the coefficients are somewhat higher than at $60 \mathrm{~kg}$.

Results of the analyses to quantify the effect of US backfat within treatments on amount of lean and fat show that increase in amount of fat tissue or decrease in amount of lean tissue with increasing backfat is different between treatments. Lean tissue at the two different degrees of coldness decreased with 1.85 to $3.01 \mathrm{~kg}$ per $\mathrm{mm}$ backfat increase (US) at $60 \mathrm{~kg}$ and with 1.86 to $3.01 \mathrm{~kg}$ at $100 \mathrm{~kg}$. The largest

Table 8. Chemical composition of three muscles in castrated males fed restricted $\mathrm{M}$ and $\mathrm{C}$ or ad libitum at the two degrees of coldness.

\begin{tabular}{|c|c|c|c|c|c|c|c|c|}
\hline \multirow{2}{*}{$\begin{array}{l}\text { Weight at slaughter }(\mathrm{kg}) \rightarrow \\
\text { Treatment } \rightarrow\end{array}$} & \multicolumn{4}{|l|}{$60 \mathrm{~kg}$} & \multicolumn{4}{|c|}{$100 \mathrm{~kg}$} \\
\hline & M & $\mathrm{C}$ & MA & $\mathrm{CA}$ & $\mathbf{M}$ & $\mathrm{C}$ & MA & $\mathrm{CA}$ \\
\hline $\begin{array}{l}\text { Protein \% in } \\
\text { fat-free matter }\end{array}$ & 20.8 & 20.6 & 20.5 & 20.7 & 21.1 & 20.9 & 21.0 & 21.0 \\
\hline $\begin{array}{l}\text { Water } \% \text { in } \\
\text { fat-free matter }\end{array}$ & 77.8 & 77.8 & 77.9 & 77.8 & 77.5 & 77.6 & 77.6 & 77.6 \\
\hline Fat $\%$ & 2.9 & 3.7 & 3.5 & $4.0^{*}$ & 3.0 & 3.4 & 3.4 & 3.4 \\
\hline Water/protein ratio & 3.75 & 3.78 & 3.80 & 3.76 & 3.68 & 3.72 & 3.70 & 3.66 \\
\hline
\end{tabular}

$* P<0.05$. 
effect was found in animals under treatments $C$ and $M(A)$. Fat tissue response with increase in backfat thickness (US) after ad libitum feeding was highest at moderate coldness (Table 6). In Table 8 the data on protein, water and fat contents in the three muscles are given.

Ad libitum feeding resulted in an increase in fat $\%$ in the muscles $(P<0.01)$. All muscles reacted similarly, therefore the results are given as mean. Water $\%$ in fat free matter was similar in all treatments. Also it seems, that coldness increased the fat $\%$ in the muscles, at both $60 \mathrm{~kg}$ and $100 \mathrm{~kg}(P<0.05)$. More fat was found in the animals fed ad libitum compared to the other animals (Table 8).

\section{Discussion}

During recent years the importance of carcass quality in fattening pigs has been strongly emphasized (Fowler et al., 1976). According to these authors, the relation between fatness or leanness of the carcass and backfat thickness is clear.

The present study was performed to evaluate the effect of a decrease in ambient temperature on carcass composition and to study the effect of additional feed in the cold to compensate for the increased heat loss for two parts of fattening period separately. This splitting of the fattening period was done to prevent exposure to an 'excessive' period of coldness since it was thought that a long period of adaptation may produce results which deviate too much from fattening conditions in practice. Too short a period of coldness, however, makes it impossible to obtain reliable estimates of rate of body weight gain and rate of gain in lean and fat tissue separately. From the results given in Tables 2 and 3 and Figs. 3 and 4 it is clear that coldness affects both lean (LTGR) and fat tissue growth rate (FTGR). At the same feeding level the lean-to-fat gain ratio is increased somewhat in the cold (Fig. 2, M and C). This agrees partly with the results of other studies which showed that in the cold fat retention was considerably more depressed than protein retention (Close, 1981). Increased percentage of lean tissue could be expected under such conditions. Hacker et al. (1973) and Brown et al. (1976) gave data which indicated a somewhat reduced water-to-protein ratio in the body. However, the effects on composition of the muscles at the two temperatures and at constant feeding ( $M$ and $C$ in Table 8) did not show such a reduction. Conditions before slaughtering may vary between experiments. In our experiments animals were transported to the slaughterhouse and generally slaughtered 2 to 3 hours after removing them from the experimental rooms.

The experimental groups at similar intake had similar lean and fat contents in the carcass at the two temperature treatments. Sometimes a higher thickness of fat (US) was found in the groups housed at the lower temperatures (Table 4). It seems as if there is a small shift in fat from backfat to sidefat. Animals in the cold and at low feeding level tended to have a slightly decreased backfat thickness and an increased sidefat thickness (Fig. 3). The variable effects of temperatures on backfat thickness were in accordance with the literature as reviewed by Holmes \& Close (1977). Total subcutaneous fat (about $60 \%$ of total fat) was similar at both temperatures. Body measurements showed that at similar feed the width of croup may be in- 
creased and carcass length slightly increased after fattening in the cold. Other experiments have shown the same effects (Sugahara et al., 1970; Holme \& Coey, 1967).

Feeding animals to similar gain $\mathrm{C}(\mathrm{P})$ and $\mathrm{M}(\mathrm{P})$ gave similar rates of lean tissue growth at the two temperatures up to $60 \mathrm{~kg}$ (Fig. 2). From 60 to $100 \mathrm{~kg}$, however, LTGR-to-FTGR ratio was reduced in animals housed in the cold C $(\mathrm{P})$ compared to those housed in moderate cold $\mathrm{M}(\mathrm{P})$. This indicated that lean tissue gain at $6 \mathrm{~K}$ coldness may be less than at $2 \mathrm{~K}$ below thermoneutrality, but that fat tissue gain was decreased less. Extra feed in the cold may thus lead to a reduction in lean-to-fat ratio in body weight gain. As expected the percentages of lean tissue in the body were somewhat diminished by the extra feed at lowest temperature. Similarly, backfat thickness was increased slightly when extra feed was given in the cold (Table 7). This agrees with results from experiments by Holme \& Coey (1967). Animals in both weight groups reacted in a similar way.

The animals at $60 \mathrm{~kg}$ had leaner carcasses than animals at $100 \mathrm{~kg}$ when compared within feeding level (Table 2). Length of the carcass after fattening at constant feeding level was not clearly affected by temperature. Width at croup was increased in the coldest group. These results agree with results of piglets which gained similarly at each of two extreme temperatures as reported by Weaver \& Ingram (1969).

Amounts of lean and fat in the carcass were significantly affected by temperature treatment if this was associated with a change in feeding level ( $P$ and $A)$. The relation between backfat thickness and amounts of lean and fat may be altered also by temperature if this is associated with different feeding level (A). At ad libitum feeding the amounts of lean and fat tissues at similar backfat thickness vary with temperatures. Under practical conditions, temperature and feeding level will not differ so extremely as in present experiments. Therefore, it may be expected that in practice fat tissue will differ somewhat less with difference in backfat thickness compared to the present experiment. It may be concluded from the present experiments that coldness does not necessarily change the lean-to-fat ratio in the body. However, if coldness is associated with increased feed intake a fatter carcass may be expected. A higher fat percentage was found in the muscles of the coldest-housed animals. Amounts of subcutaneous fatty tissue were not clearly affected by temperature in the pig in the trials with similar gain and in the ad libitum trials. Total amounts of subcutaneous fat do not coincide with the amounts of fat in the muscle. This agrees with conclusions of Richmond \& Berg (1971), Fowler et al. (1976) and Walstra (1980). The latter stated that subcutaneous fat rather than intermuscular fat increased more with the increase of fatness in the body.

\section{Conclusion}

Experiments carried out show clearly that the effects of the different degrees of coldness during fattening on the carcass composition were much smaller than the effects of the change in feeding level. Coldness, as such, seems to be associated with some increase in fatness since at similar rate of gain lean to fat in carcasses are reduced after fattening at the lower temperatures. At identical feed intake, coldness 
is associated with a reduced amount of feed for production and, as a consequence, a reduction in fatness of the body. Ad libitum feeding of animals in the cold leads to an increased gain in both lean and fat tissue compared to those in warmer surroundings and a fatter carcass. It was concluded that the relation between backfat thickness measured ultrasonically and the amounts of lean or fat tissue may be altered by feeding level in the colder condition.

\section{References}

Bergstrom, P. L. \& D. Kroeske, 1968. Methods of carcass assessment in research on carcass quality in the Netherlands. I. Description of the methods. Proceedings EAAP Meeting (Dublin), $11 \mathrm{pp.}$

Brown, D. E., R. R. Hacker \& G. J. King, 1976. Growth and ATCH responses to cold stress in young pigs fed ad libitum. Canadian Journal of Animal Science 56: 365-371.

Close, W. H., 1981. The climatic requirements of the pig. In: J. A. Clark (Ed.), Environmental aspects of housing for animal production, pp. 147-166. London, Butterworths.

Close, W. H. \& L. E. Mount, 1967. Gains in protein and fat in the growing pig in relation to environmental temperature. Proceedings 7th Symposium on Energy Metabolism (Vichy), EAAP Publication No 19 , pp. 173-176.

Comberg, G., E. Stephan \& H. Späth, 1971. Zur Problematik der Klima-empfindlichkeit von Haustieren: Die Reaktion von Ebernachkommengruppen der Deutschen Landrasse auf verschiedene stallklimatische Bedingungen, Züchtungskunde 43: 255-267.

Comberg, G., R. Plischke, W. Wegner \& H. Feder, 1972a. Die Auswerkung suboptimaler Temperaturen $\left(+8^{\circ} \mathrm{C}\right)$ auf die Leistungen von Pietrains, Belgischen Landrasse und deren Kreuzungen, Züchtungskunde 44: 91-98.

Comberg, G., E. Stephan \& H. Späth, 1972. Die Reaktion von Ebernachkommengruppen der Deutschen Landrasse auf verschiedene stallklimatische Bedingungen. Züchtungskunde 44: 402-415.

Davies, A. S. \& W. J. Pryor, 1977. Growth changes in the distribution of dissectable and intramuscular fat in pigs. Journal of Agricultural Science, Cambridge 89: 257-266.

Fowler, V. R., M. Bichard \& A. Pease, 1976. Objectives in pig breeding. Animal Production 23: 365 382.

Fuller, M. F. \& A. Boyne, 1971. The effects on environmental temperature on the growth and metabolism of pigs given different amounts of food. 1. Nitrogen metabolism, growth and body composition. British Journal of Nutrition 25: 259-272.

Hacker, R. R., M. P. Stefanovic \& T. R. Batra, 1973. Effects of cold exposure on growing pigs: growth, body composition and 17 ketosteroids. Canadian Journal of Animal Science 37: 739-744.

Holme, D. W. \& W. E. Coey, 1967. The effects of environmental temperature and method of feeding on the performance and carcass composition of bacon pigs. Animal Production 9: 209-219.

Holmes, C. W. \& W. H. Close, 1977. Influence of climatic variables on energy metabolism and associated aspects of productivity in the pig. In: W. Haresign, H. Swan \& D. Lewis (Ed.), Nutrition and the climatic environment, pp. 51-73. London, Butterworths.

Piatkowski, B., 1958. Untersuchungen über den Einfluss niedriger Umgebungstemperaturen auf den Stoffwechsel wachsender Schweine. Archiv für Tierernährung 8: 161-181.

Richmond, R. T. \& R. T. Berg, 1971. Fat distribution in swine as influenced by live weight, breed, sex and ration. Canadian Journal of Animal Science 51: 523-531.

Simmermans, J. \& J. Stadler, 1976. Klimaatstallen voor dieren van het IVO te Zeist. Klimaatbeheersing 5: $406-411$.

Sorensen, P. H., 1962. Influence of climatic environment on pig performance. In J. T. Morgan \& D. Lewis (Ed.), Nutrition of pigs and poultry, pp. 88-103. London, Butterworths.

Sugahara, M., D. H. Baker, B. G. Harmon \& A. H. Jensen, 1970. Effect of ambient temperature on performance and carcass development in young swine. Journal of Animal Science 31: 59-62.

Verstegen, M. W. A. \& W. van der Hel, 1974. The effects of temperature and type of floor on metabolic rate and effective critical temperature in groups of growing pigs. Animal Production 18: 1-11. 
Verstegen, M. W. A., W. H. Close, I. B. Start \& L. E. Mount, 1973. The effects of environmental temperature and plane of nutrition on heat loss energy retention and deposition of protein and fat in groups of growing pigs. British Journal of Nutrition 30: 21-35.

Verstegen, M. W. A., E. W. Brascamp \& W. van der Hel, 1978. Growing and fattening of pigs in relation to temperature of housing and feeding level. Canadian Journal of Animal Science 58: 1-13.

Verstegen, M. W. A., G. Mateman, H. A. Brandsma \& P. I. Haartsen, 1979. Rate of gain and carcass quality in fattening pigs at low ambient temperatures. Livestock Production Science 6: 51-60.

Verstegen, M. W. A., H. A. Brandsma \& G. Mateman, 1982. Feed requirement of growing pigs at low environmental temperatures. Journal of Animal Science 55: 88-94.

Walstra, P., 1980. Growth and carcass composition from birth to maturity in relation to feeding level and sex in Dutch Landrace pigs. Mededelingen Landbouwhogeschool Wageningen 80-4; $201 \mathrm{pp}$.

Weaver, M. E. \& D. L. Ingram, 1969. Morphological changes in swine associated with environmental temperature. Ecology 50: 710-713. 